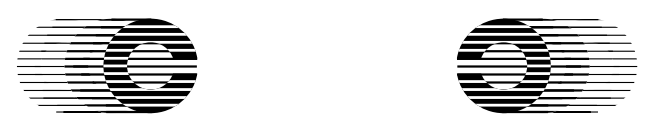

\section{勝手に動く超分子システムをつくる -さらなる生物らしさをめざして -}

\section{東京医科歯科大学生体材料工学研究所 日本学術振興会特別研究員 野村 M. 慎一郎}

\section{1.はじめに}

人か甡き物を見て感じる「生物らしさ」には, 死て終 わるまで動き続けること, 殖えることを基本に, 治る/ 進む/逃げる/迷う/慣れるなどなどの動きが学げら れよう. エネルギーの出入りがある中で, これらの動き が勝手に生じる条件を自らつくる存在こ光が生物であ るとも言えよう. 生物の基本単位は $\mu \mathrm{m}$ スケールの細胞 である. 細胞は脂質分子と膜タンパクとの超分子集合 体 ${ }^{* 1}$ からなる膜によって自他を分離し, 内封した遺伝子 発現と酵素反応ネットワークに基づく外界とのクロス トークの結果, 我々に生物らしさを感じさせている. こ のような存在をつくりだ光うとする人工細胞・人工生 命への実験的アプローチは数多くあるが (最近では Deamer ${ }^{1)}$, Szostak $^{2}$ など), 本稿では「勝手に動く」とい

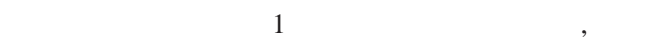
クロスケールで勝手に動く超分子システムをつくる試 みについて紹介する. まず, 脂質二分子膜製のチューブ 構造が勝手に往復運動を繰り返す系について, 次に, リ ポソーム*2 内で化学反応が勝手に進行する系を構築す る試みについて述べる.

*1 超分子構造, すなわち非共有結合による多数の分子 の自己組織体であるということは, 構造が「勝手に できる」ということであり, 構築に要するエネルギ 一のコストが小さくてすむ．

*2 リポソーム (liposome) : 脂質二分子膜の閉じた球 状小胞をさす. 本稿では直径 1-10 $\mu \mathrm{m}$ のもを細胞 サイズとよぶ.

\section{2. 勝手に往復運動をする脂質チューブ}

細胞のような水溶液中の $\mu \mathrm{m}$ スケールの空間では慣 性運動は生じない. よって, 物体を動かし続けるために は常に力を加え続ける必要がある. 弚してたとえば, エ ネルギー流の中で系の性質として常に平衡点を行き過 ぎ, しかし平衡点へと引き戻される振る舞いを示せば 連続した往復運動が生じるであろう.ここでは勝手に 動くシステムの例として, 筆者らの実現した, 脂質二分 子膜からなるチューブ構造の往復運動を紹介する ${ }^{3)}$. 膜 の表面積が一定であると仮定すると, 膜の等方的張力 $F$ は温度変化 $d T$ に対し $d F=-K d T$ という応答を示す $(K \text { は張力に関する正の定数 })^{4)}$, つまり, 温まると張力は 小さくなる. 系に与えるエネルギ一源としては, 赤外レ 一ザートラップの焦点を中心に直径約 $1 \mu \mathrm{m}$ の領域のみ が局所加熱される現象を用いた.レーザー光学系の工 夫により双安定な捕捉ポテンシャル場が焦点付近に形 成される (Fig.1a). 焦点に捕捉された脂質チューブ構 造は2つのうちいずれかの捕捉場に配向する.レーザー を連続照射する間, チューブが2つの捕捉場を秒のオー ダーの時間スケールで往復する樣子が観察された (Fig.1b).この系では, チューブの直径以下の領域で不 均一な温度場が形成されているため, 同一膜上におい て局所的な張力の違いができ, チューブ全体が曲がる ことで別の捕捉場へと動いていると推察される (Fig.1c).

この脂質チューブが示すメトロノーム樣の往復振動 実験では, 超分子集合体の構造と物性, 弚して適切な工 ネルギーの注入・散逸, および, 弚れに伴うフィードバ ックを利用することで, 時間周期性のある「動き」が得 られた. ほかの系でも, 対象か動くための適切な条件 · 特性を読み切ることができれば「勝手に動く系」は同 樣に設計・制御できるであろう (同アイディアは単一 荷電高分子の折りたたみ・解きほぐしの高次構造変化 に対しても適用され実現されだ5).

\section{3. 勝手に動く「可能性のある」リポソーム系}

次に,物質透過を制限する膜で溶液空間を閉じた構造 である細胞サイズのリポソームを動かす試みについて 述べる. まずリポソームが提供する $\mu \mathrm{m}$ スケールの内部 空間の特徴をみよう. $\mu \mathrm{m}$ スケールつまり fLオーダーの

\title{
Making of Supramolecular System for Autonomous Working
}

Shin-ichiro M. NOMURA

Department of Organic Materials, Institute of Biomaterials and Bioengineering, Tokyo Medical and Dental University 
(a)

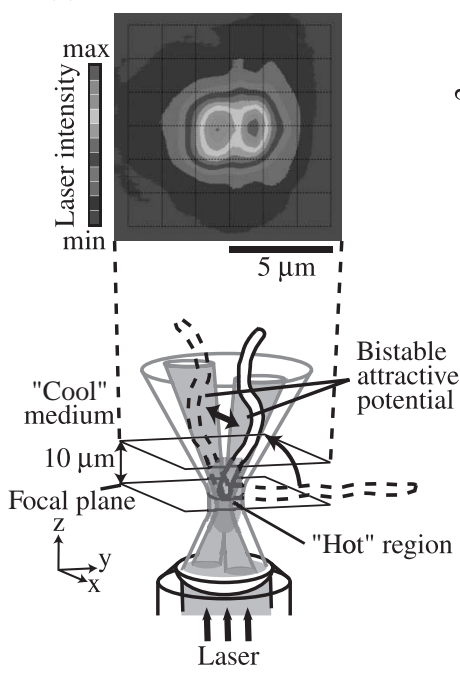

(b)

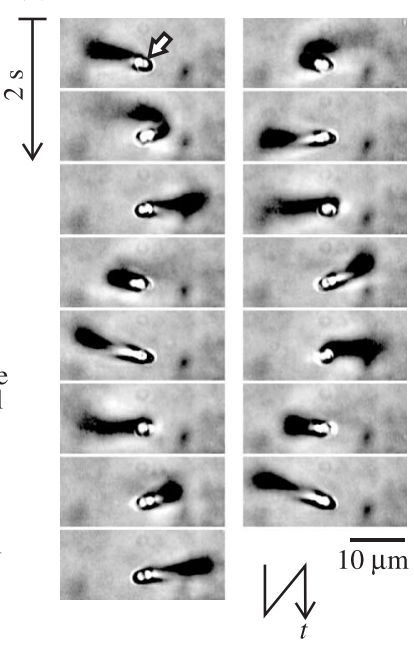

(c)

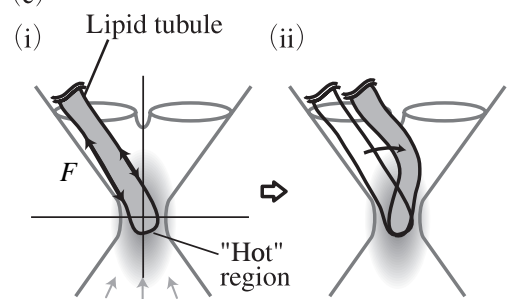

Laser (iv)

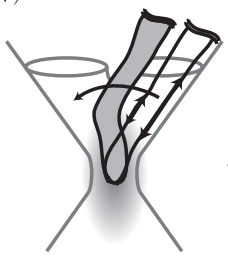

3

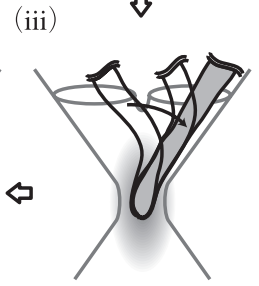

Fig.1 ( a) Upper : Spatial distribution of the laser intensity at $10 \mu \mathrm{m}$ from the focal plane. Lower : Schematic image of lipid tubule oscillation. The tubule oscillates between the two attractive potential wells created around the regions with maximum laser intensity. ( b) Sequential images of lipid tubule oscillation at laser power of $50 \mathrm{~mW}$. ( c) Scheme of an optically trapped lipid tubule oscillation. ( $i)$ First, the tubule is trapped in either one of the potential wells. A "root" of the tubule is then locally heated. The resulting temperature gradient around the tubule loses tension $(F)$ on the proximal side of the tubule. ( ii) -( iii) The imbalance in tension between the proximal and distal sides drives the tubule toward the other side of the bistable potential. After transient swinging, the distal side cools down( iv), and the cycle repeats ${ }^{3)}$.

体積の溶液内では分子は単純拡散のみで激しく混合さ れるため, 反応力昿散律速となることはない. また, 表面 積/体積比が大きくなり, 表面の効果を無視できなく なる,すなわち膜表面近傍では不均一な反応が進行す る可能性が大きい. 产の例として, 脂質分子・脂質膜の 共存下において, 変性したタンパク質の天然状態への 折りたたみと膜への取り込みが促進されるという報告 がある6).これらの特徵から, リポソーム内で行われる 溶液実験系は, ガラスの試験管で行われる実験系とは 異なる, しかし興味深い結果をもたらすことか想像で きる. このようなリポソームを「勝手に動く」系とする には, 特異な分子の膜を介した物質の注入・放出によ るエネルギー流が必要である. 兴の上で, リポソーム内 水相の化学反応系か動くことと, 脂質膜自体か動くこ とが生物らしさを醸す上で外すことのできない車の両 輪となるだろう.

まず, 生物らしく動く溶液化学反応系として, 巨視系 での実例をみてみよう. 時間周期性を示す化学反応の 例としてBZ (Belousov-Zhabotinsky) 反応か有名であ る. この反応では溶液内の酸化還元電位が周期的に変 化し,混ぜておくだけで「勝手に」時空間のパターンを 生じる. 最近, BZ 反応溶液に共存させた高分子の凝縮 -
溶解が, 反応に対応して周期的に变化する樣子か観察 されている71. 混ぜるだけて進行する生物らしい反応と いう意味でin vitro 酵素反応系を小サイズのリポソーム で行う研究は多く,バクテリオロドプシンとATPase の 共存などさまざまな手法で実現されている(詳細は Walde らの総説8などを参照されたい). 問題となるの は細胞サイズの系でいかに反応系を動かし, 兴の動き を測定するか?という点である.

細胞サイズのリポソームを含む溶液は, 均一系ではな くなるために分光光度計などで平均值を求める定量手 法が非常に使いづらくなる欠点がある. これを補うた めには, 細胞のふっるまいを追う場合と同樣に, 顕微鏡に よる直接観察手法力望ましい. 近年, 光学顕微鏡により 細胞サイズのリポソームのダイナミックな構造変化が 確認されてきている91. 特にリポソーム内に封入した溶 液の時間発展性に着目すると, 反応のわずかな進行を も確認できる技術が必要となる. 筆者らは, 細胞サイズ リポソームの形成法と光学顕微鏡による単一分子観察 の手法を改良することで, 生体高分子を内封した細胞 サイズリポソームの形成および内封された長鎖DNA 分子の高次構造の実時間直接観察法を確立してきて いる ${ }^{10)}$.さらに, DNAからRNAへの転写反応の進行を 


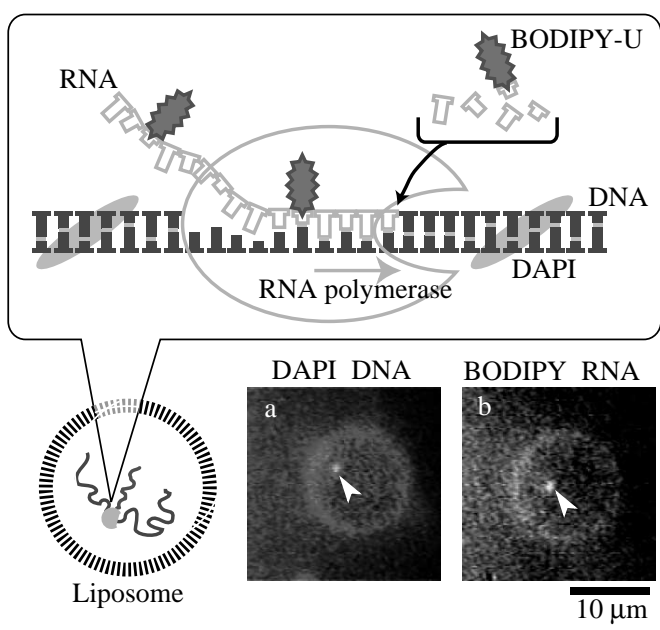

Fig.2 Schematic illustration and experimental images of a giant liposome entrapping T7 DNA and the transcripts ${ }^{11}$. ( a) Fluorescence images of DAPI on T7 DNA entrapped in the liposome. ( b) Fluorescence images of BODIPY on RNA in the same liposome as a. Here, RNA transcripts are observed in the state of binding to T7 DNA.

リアルタイムに直接観察する手法を確立している ${ }^{11}$. Fig.2に光の観察例を示す.リポソームに内封されてい るのは, 蛍光色素DAPIにて染色されたDNA上で, RNA (蛍光標識されたUTPを含む) がRNAポリメラーゼに よって合成される反応である. 外部からのRNAse添加 に対してもリポソーム内部のRNAの蛍光シグナルは 安定であった.

最近ではリポソーム内での蛍光タンパク質 (green fluorescence protein) の合成も報告されている ${ }^{12}$. 筆者 らも同樣のデモ実験に成功しており, リポソーム内に おけるRNAやタンパク質の合成に代表される低分子 から高分子を形成する化学反応系では, 高分子の折り たたみや高分子同士の結合による高次構造の形成を通 じて (細胞同樣に) リポソーム自体をダイナミックに 動かすことか期待できる. 実際, リポソーム内にてアク チンや微小管が重合する過程でリポソームか変形して いく樣子か観察されている(13), 14). 一方, 閉鎖空間に封入 されたまま動き続ける化学反応系を考える場合, 消費 された基質を補充し, 反応生成物を排出するからくり が必要となる. BZ反応ではCSTR (連続循環反応槽) としてこれか実現されており, 外部からエネルギーの 連続的な注入が行われている. リポソームの系ではエ ネルギーとなる分子としてATPなどの外部からの導入 が求められるが, 脂質二分子膜の物質透過能は特に親 水性分子について悪く,たとえば膜を介したD-グルコ
ースの移送には内外に $10^{8}$ 倍以上の濃度差が必要とな る. 電荷をもつATPではさらに悪い.これを解決するた めには, 膜を動かすというアプローチとのカップリン グが重要と考えられる.

リポソームは反応容器として安定なガラスや樹脂と は異なり, 脂質分子同士の弱い非共有結合によって構 成されている. よって, ほかの両親媒性分子の侵入過程 や弚の分子形状に起因して, 変形・破壊などといった かたちで容器自体に変化が生じ得る.これまでにリポ ソームの自己触媒的な増加 ${ }^{15)}$, 膜の間欠的な振動や小 胞放出など(16), 17)の興味深い動的構造変化か報告されて きている. また, 最近筆者らのグループは, 脳・神経細胞 に特に多く存在している糖脂質の一種であるガングリ オシドを細胞サイズリポソームに添加することで安定 なチューブ・リポソームネットワーク構造が誘起され ることを明らかにした ${ }^{18)}$. 分子の可逆的流入 ・流出過 程など外部の制御系を工夫し, フィードバックを導入 する (困難であろうが) ことで膜は変化し動き続ける であろう. 光して, 前出のリポソーム内での化学反応系 より両親媒性分子や膜タンパクが生成されると, 光の 結果膜のダイナミックな構造変化が生じてサイトーシ ス的な物質輸送や物質透過能を上昇させ, 膜を介した エネルギー流を生じる‥という展開も考えられる.

\section{4 . 展望}

現状では, $\mu \mathrm{m}$ スケールの勝手に動くシステムはまだ デモンストレーションの粋を出ないように思える. し かし, 少しずつ生物「らしさ」を実現していく点に意味 があると筆者は考えている. 弚れは現実にある要素・ ふるまいを1つ1つヒトの制御下におき, 理解すること につながる. 产の上で, 「勝手にできる」超分子系の制 御とは量の変化により現れる質の違いを活用するもの であり, 生物の用いる戦略をヒトが使えるようにする という意義がある.ここで述べた「動く」システムはま だ外から「動かされ」ている性格か強い、リポソーム内 の化学反応系がエネルギーを取り込み, 分子レベルの フィードバックをもち, 反応を制御する中で系全体が 時間発展をするようになるのはまだ先の話であるが, 兴の研究の先には医療に役立つ人工細胞や, 新たな知 的エンタテインメントが待っているかもしれない.

\section{謝 辞}

本稿に紹介した研究は京都大学大学院理学研究科吉 川研究室とフランス Louis Pasteur 大学の Ourisson \& Nakatani 研究室, 光して東京医科歯科大学生体材料工学 研究所秋吉研究室との共同の仕事であり, 本文に引用し 
た原報3)，10)，11，18) の共著者に厚く感謝します. また平成 13 年度 14 年度日本学術振興会特別研究員 (No.03257) としてサポートをいただいたものであり, 厚く感謝し ます.

\section{文 献}

\section{(入門向け)}

滝口金吾 (2000) シリーズ・ニューバイオフィジックス II-5「細胞のかたちと運動」(日本生物物理学会 編) pp.47-63, 共立出版, 東京.

1) Pohorille, A. and Deamer, D. (2002) TRENDS in Biotechnology 20, 123-128.

2) Szostak, J. W. et al. (2001) Nature 409, 387-390.

3) Nomura, S.-i. M. et al. (2001) Phys. Rev. Lett. 88, 93903.

4) Cevc, G. and Marsh, D. (1987) Phospholipid Bilayers, pp.361-364, John Wiley \& Sons, Tronto.

$5)$ Mayama, H. et al. (2000) Chem. Phys. Lett. 330, 361-367.

6) Bogdanov, M. and Dowhan, W. (1999) J. Biol. Chem. 274, 36827-36830.
7) Yoshida, R. et al. (2002) J. Am. Chem. Soc. 124, 80958098.

8) Walde, P. and Ichikawa, S. (2001) Biomol. Eng. 18, 143-177.

9) Hotani, H. et al. (1999) Current Opinion in Colloid \& Interface Science 4, 358-368.

10) Nomura, S.-i. M. et al. (2001) CHEMBIOCHEM 6, 457459.

11) Tsumoto, K. et al. (2001) Langmuir 17, 7225-7228.

12) Yu, W. et al. (2001) J. Biosci. Bioeng. 92, 590-593.

13) Kaneko, T. et al. (1998) J. Mol. Biol. 284, 1671-1681.

14) Miyata, H. and Hotani, H. (1992) Proc. Natl. Acad. Sci. USA 89, 11547-11551.

15) Wick, R. et al. (1995) J. Am. Chem. Soc. 117, 14351436.

16) Saitoh, A. et al. (1998) Proc. Natl. Acad. Sci. USA 95, 1026-1031.

17) Nomura, F. et al. (2001) Proc. Natl. Acad. Sci. USA 98, 2340-2345.

18) Akiyoshi, K. et al. (2003) FEBS lett. 534, 33-38. 